\title{
Inhibitory Effects of Phyllostachys bambusoides on Melanin Synthesis and Tyrosinase Activity in Cultured Human Melanoma Cells
}

\author{
Man Kyu Huh ${ }^{1 *}$, Min Ho Han ${ }^{2,3}$, Cheol Park ${ }^{1}$ and Yung Hyun $\mathrm{Choi}^{2,3}$ \\ ${ }^{1}$ Department of Molecular Biology, College of Natural Sciences, Dongeui University, Busan 614-714, Korea \\ ${ }^{2}$ Department of Biochemistry, Dongeui University College of Oriental Medicine, Busan 614-052, Korea \\ ${ }^{3}$ Anti-Aging Research Center \& Blue-Bio Industry RIC, Dongeui University, Busan 614-714, Korea
}

Received February 11, 2014 / Revised February 28, 2014 /Accepted February 28, 2014

\begin{abstract}
Tyrosinase is a rate-limiting enzyme that controls the production of melanin. The effect of bamboo (Phyllostachys bambusaides) on tyrosinase activity and melanin synthesis has not been studied. We analyzed the effects of leaf and inner film fractions of bamboo extracts on the inhibition of tyrosinase activity and on melanin production. At a concentration of $5 \mathrm{mg} / \mathrm{ml}$, the extracts of bamboo downregulated the production of melanocytes. In addition, the extracts of bamboo reduced tyrosinase activity and the melanin content in vitro. Our results suggest that bamboo extract may constrain melanin synthesis by inhibition of the activity and expression of tyrosinase.
\end{abstract}

Key words : Bamboo, extractions, melanocyte, tyrosinase activity, melanin

\section{Introduction}

Visible pigmentation in mammals results from the synthesis and distribution of melanin in skin, hair bulbs and eyes [15]. At the cellular level, melanins are produced in pigment cells (melanocytes) in a specialized cytoplasmic organelle (melanosome) [4].

The melanocyte is a neutral crest-derived cell that localizes in the bottom layer (the stratum basale) of the skin's epidermis, the middle layer of the eye (the uvea) to several organs including the epidermis, eyes, inner ear, bones and heart. Melanocytes can absorb ultraviolet radiation and survive considerable genotoxic stress. The skin is the primary barrier to the external environment, and relies on melanocytes to provide, among other things, photo-protection and thermoregulation by producing melanin. The degree of pigment production shows as skin 'phototype' (skin color and ease of tanning) in the general population [10]. Melanin is the pigment primarily responsible for skin color and it can role in the most useful predictor of human skin cancer risk [3].

\footnotetext{
*Corresponding author

Tel : +82-51-890-1521, Fax : +82-51-890-1529

E-mail : mkhuh@deu.ac.kr

This is an Open-Access article distributed under the terms of the Creative Commons Attribution Non-Commercial License (http://creativecommons.org/licenses/by-nc/3.0) which permits unrestricted non-commercial use, distribution, and reproduction in any medium, provided the original work is properly cited.
}

The tyrosinase is the rate-limiting enzyme for controlling the production of melanin [13]. It is mainly involved in two distinct reactions of melanin synthesis. One is the hydroxylation of a monophenol and the other is the conversion of an o-diphenol to the corresponding o-quinone which undergoes several reactions to eventually form melanin [9]. Tyrosinase is a copper-containing enzyme present in plant, animal tissues and fungal species that catalyzes the production of melanin and other pigments from tyrosine by oxidation, as in the blackening of a peeled or sliced potato exposed to air. It is found inside melanosomes [14].

Several polyphenols, including flavonoids or stilbenoid, substrate analogues, free radical scavengers, and copper chelators, have been known to inhibit tyrosinase [2]. Henceforth, the medical and cosmetic industries are focusing research on tyrosinase inhibitors to treat skin disorders.

Tyrosinase is the key enzyme in pigment synthesis, initiating a cascade of reactions which convert the amino acid tyrosine to the melanin biopolymer. Two other tyrosinase-related proteins (TRP) are known, TRP-1 (probably DHICA oxidase) and TRP-2 (DOPA chrome tautomerase).

Bamboo (Bambuseae) is a tribe of flowering perennial evergreen plants in the grass family Poaceae, subfamily Bambusoideae, tribe Bambuseae. Bamboos are of notable economic and cultural significance in South Asia, Southeast Asia and East Asia, being used for building materials, as a food source, and as a versatile raw product. Bamboo is also used in Chinese medicine for treating infections and healing. All the bamboo materials have a mild sweet taste 
and all parts but the leaves are used to resolve phlegm. While the phlegm disorder to be addressed may be related to lung heat causing coughing and sticky phlegm, bamboo is especially used for the disorder of hot phlegm that coats or obstructs the "orifices of the heart", affecting the brain functions. Thus, it is used for epilepsy, fainting and loss of consciousness in feverish diseases, and a variety of mental disorders that develop with aging.

The present investigation was undertaken to evaluate the inhibition of tyrosinase activity and expression ether extracts of bamboo (Phyllostachys bambusoides).

\section{Materials and Methods}

\section{Material}

Phyllostachys bambusoides Sieb. et Zucc., a genus of grass family Gramineae (Poaceae) consists of diploid species ( $2 n=$ 48). This species is native to China, but it is commonly worldwide grown, especially in Korea and Japan. Most species of the genus are economically important. For example, plant leaves, stems, and roots, which historically were used in Korea for building and in the manufacture of furniture. Fifty mature trees $(\geq 3 \mathrm{yr})$ were randomly collected from P. bambusoides.

\section{Fraction of active constituents from the ethanol extract}

P. bambusoides was collected from natural populations and its leaves dried in shade. HCl-ethanol extractions were obtained using $100 \mathrm{~g}$ leaves. In addition, bamboos split in half with a knife. Films of stems were collected from the inner wall of bamboos. $100 \mathrm{~g}$ of films were added to $50 \mathrm{ml}$ distilled water and homogenized in homogenizer with 3,000 rpm for $2 \mathrm{~min}$. Plant tissues were pulverized in liquid nitrogen (-7 $\left.0^{\circ} \mathrm{C}\right)$ using a mortar and pestle. Homogenous powder was transfer to $\mathrm{HCl}$-ethanol and their solutions were treated in

Table 1. Inhibitory effects of bamboo extracts and comparison of inhibitors

\begin{tabular}{llc}
\hline Group & Content & $\begin{array}{c}\text { Extracts } \\
(\mathrm{mg} / \mathrm{ml})\end{array}$ \\
\hline Control 1 & Cell + broth + Water & - \\
Control 2 & Cell + broth + a-MSH + Albutin & - \\
& & 0.25 \\
Treatment & Cell + broth + a-MSH + extracts & 0.50 \\
& & 0.75 \\
& & 1.00 \\
\hline
\end{tabular}

an ultrasonic bath for $90 \mathrm{~min}$. Samples were dried and ground hydro-distilled for $2.5 \mathrm{hr}$ using a Clevenger-type apparatus. The components were extracted from the distillate with ether, and then dried with anhydrous $\mathrm{Na}_{2} \mathrm{SO}_{4}$. The solvent was removed by distillation at atmosphere pressure, and the pure dried extraction was kept at $4{ }^{\circ} \mathrm{C}$ until analysis.

\section{Cells and culture media}

Melanin cells (B16F10) were used. The culture media were in Dulbecco's modified eagle medium (DMEM) with penicillin/streptomycin, $10 \%$ phosphate buffered saline (FBS) 50 $\mathrm{ml}$, Bovine pituitary extracts $2.0 \mathrm{ml}$, FGF $1.0 \mathrm{ml}$, Insulin 1.0 $\mathrm{ml}$, Hydrocortisone $0.5 \mathrm{ml}$, Phorbolmyristate acetate $0.5 \mathrm{ml}$, GA-1000 $0.5 \mathrm{ml}$, and Fetal bovine serum $2.5 \mathrm{ml}$.

\section{Cell viability}

Melanin cells were divided into nine groups and each group treated with $0,0.5,1.0,2.5,3.0,3.5,4.0,4.5$, and 5.0 $\mathrm{mg} / \mathrm{ml}$ extracts of $P$. bambusoides. Group-I is control which treated with DMSO (Dimethylsulfoxide) and $50 \mu \mathrm{g} / \mathrm{ml}$ albutin [17]. Cells were incubated in $\mathrm{CO}_{2}$ at $37^{\circ} \mathrm{C}$ for $72 \mathrm{hr}$. After removing media, $0.5 \mathrm{mg} / \mathrm{ml}$ tetrazolium bromide salt (MTT) was added and were incubated in $\mathrm{CO}_{2}$ at $37^{\circ} \mathrm{C}$ for $32 \mathrm{hr}$. Afterremoving MTT, $1 \mathrm{ml}$ DMSO was added and absorbancemeasuredusing ELISA reader (Molecular Devices, Sunnyvale, CA, USA).

\section{Tyrosinase activity}

Inhibitory effects against tyrosine were carried out the following procedure. Inhibitory effects against tyrosine were carried out the following procedure [6]. The reaction mixture containing various concentrations of the test samples and 4-hydroxyphenyl alpha-glucopyranoside, alpha-arbutin $50 \mathrm{\mu g} /$ $\mathrm{ml}$. Sodium phosphate buffer $(60 \mu \mathrm{l}, 50 \mathrm{mM})$ at $\mathrm{pH} 6.8,30$ $\mu$ tyrosinase $(25 \mathrm{U} / \mathrm{ml})$ and $10 \mu$ of the plant extract were inserted into 96-well plates. After $5 \mathrm{~min}$ of incubation at room temperature, $100 \mu \mathrm{l}$ L-tyrosine $(2 \mathrm{mM})$ were added and incubated for additional $20 \mathrm{~min}$. The optical density (OD) of the samples at $475 \mathrm{~nm}$ (EL800, BIO-TEK Instruments, USA) were measured compared to control without inhibitor, demonstrating a linear color change with time during the $20 \mathrm{~min}$ of the experiment. Control incubations represent $100 \%$ enzyme activity and were conducted in a similar way by replacing extracts by buffer. For blank incubation, to allow for absorbance (A) produced by the extract, the enzyme 
solution was replaced by buffer. The inhibitory activity was determined by comparing the enzyme activity in the absence and presence of the evaluated inhibitor. $0.2 \mu \mathrm{M}$ a-MSH was used as positive control. Albutin was also used as control [11].

\section{Measurement of cellular melanin contents}

Measurement of cellular melanin contents was carried out as previously described by Hosei et al. [4]. B16F10 melanin cells were cultured in $5 \% \mathrm{CO}_{2}$ at $37^{\circ} \mathrm{C}$ for 3 days with MSH.Cells were washed with PBS and separated by centrifugation at 1,500 rpm for 5 . The pellets were solubilized in $1 \mathrm{~N} \mathrm{NaOH}$ containing 10\% dimethyl sulfoxide (DMSO) at $80^{\circ} \mathrm{C}$ for $1 \mathrm{hr}$. After washing with washing solution, they were treated $100 \mu \mathrm{l}$ enzyme conjugate and incubated at $22^{\circ} \mathrm{C}$ for $45 \mathrm{~min}$. The O.D. was measured at $475 \mathrm{~nm}$ using microplate reader (EL800, BIO-TEK Instruments, USA).

\section{Results and Discussion}

The effects of the various fractions of bamboo extract on $\mathrm{HCl}$-ethanol were investigated, and the results were shown in Figs. 1 and 2. Fig. 1 was the results of B16F10 (Primary Human Melanocytes) cells grown in medium with the addition of Human Melanocyte Growth Supplement (HMGS) after $48 \mathrm{hr}$. As concentration of leaf and inner film extractions increased, the cell growth was inhibited. Thus, extractions of the leaves and inner film had an effect the survival rate for melanin cells. Compared to this control, treatments with various concentrations did not decrease significantly at 48 $\mathrm{hr}$. However, when the proceeding time has longer, inhibitory effect was found. For example, the reduction was shown significantly at $72 \mathrm{hr}$. Cell survival rate on $5 \mathrm{mg} / \mathrm{ml}$

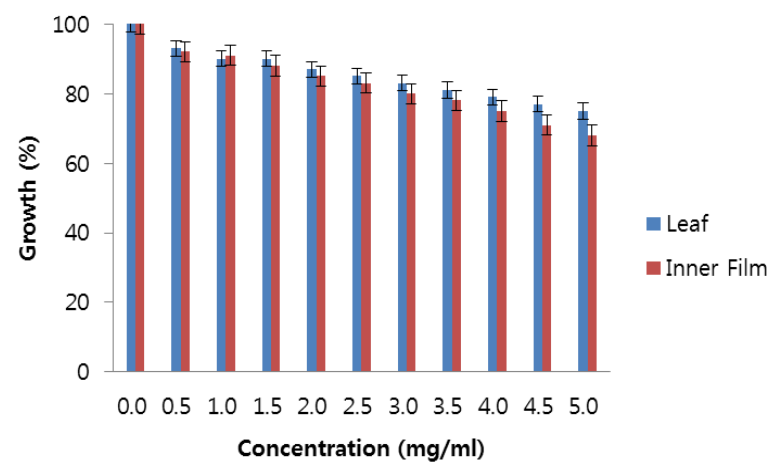

Fig. 1. B16F10 (Primary Human Melanocytes) cells grown in medium with the addition of Human Melanocyte Growth Supplement (HMGS) after $48 \mathrm{hr}$.

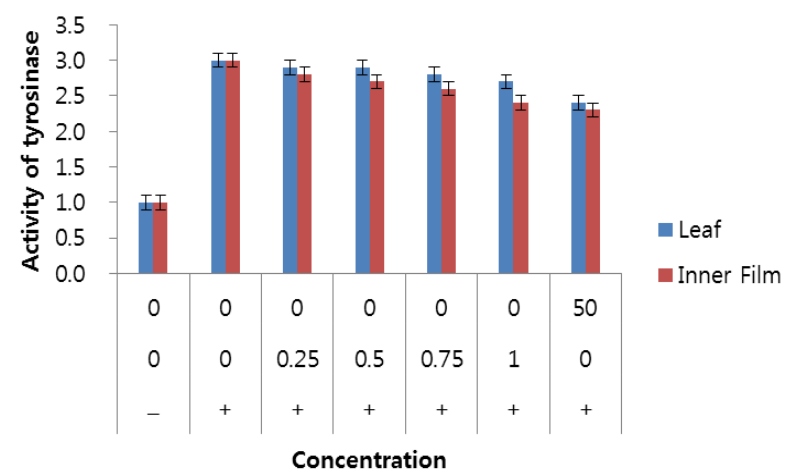

Fig. 2. B16F10 cells grown in medium with the addition of HMGS after $72 \mathrm{hr}$.

concentration of leaves and inner film were shown $75 \%$ and $50 \%$, respectively.

Cell viability which was treatment with extracts on $72 \mathrm{hr}$ observed by microscope (Fig. 3). The morphological character and melanocyte cell density did not show any change in the $1.0 \mathrm{mg} / \mathrm{ml}$ treated group. But the $2.0 \mathrm{mg} / \mathrm{ml}$ treatment groups were decreased overall cell density and observed morphologically change. Fig. 4 was shown the inhibitory effects of inner film compounds on intra cellular tyrosinase activity in melanin cells at $72 \mathrm{hr}$ after treatment. As concentration of leaf and inner film extractions increased, the cellular tyrosinase activity was inhibited. Inhibition of inner film for tyrosinase is higher than that of leaves.

In order to determine the effects of a-MSH on melanogenesis, melanin cell were treated with the bamboo extracts. $0.2 \mu \mathrm{M}$ a-MSH induced mild stimulation of the tyrosinase activity in melanoma cells. In contrast, the addition of bamboo extracts in to the cells led to a significant decrease in the activity and synthesis of tyrosinase, regardless of the presence or absence of a-melanocyte stimulating hormone (a-MSH) (Fig. 5). Moreover bamboo extracts $(1.0 \mathrm{mg} / \mathrm{ml}) \mathrm{di}-$ minished the expression and activity of tyrosinase, and melanin content in cultured normal human epidermal melanocytes. We studied the inhibitory effects of 4-hydroxyphenyl alpha-glucopyranoside (alpha-arbutin) on melanogenesis in cultured human melanoma cells. The melanin content was found significantly to be decreased by bamboo extracts in a concentration-dependent manner (Fig. 5). Melanin synthesis in cells treated with alpha-arbutin at $50 \mu \mathrm{g} / \mathrm{ml}$ decreased to $70 \%$ of that in non-treated cells. The cellular tyrosinase activity of melanin cells also significantly decreased. While melanin synthesis was reduced to $25 \%$ of that in the control. Although the in vivo effects of bamboo extracts are still unclear, these results suggest that bamboo extracts could 


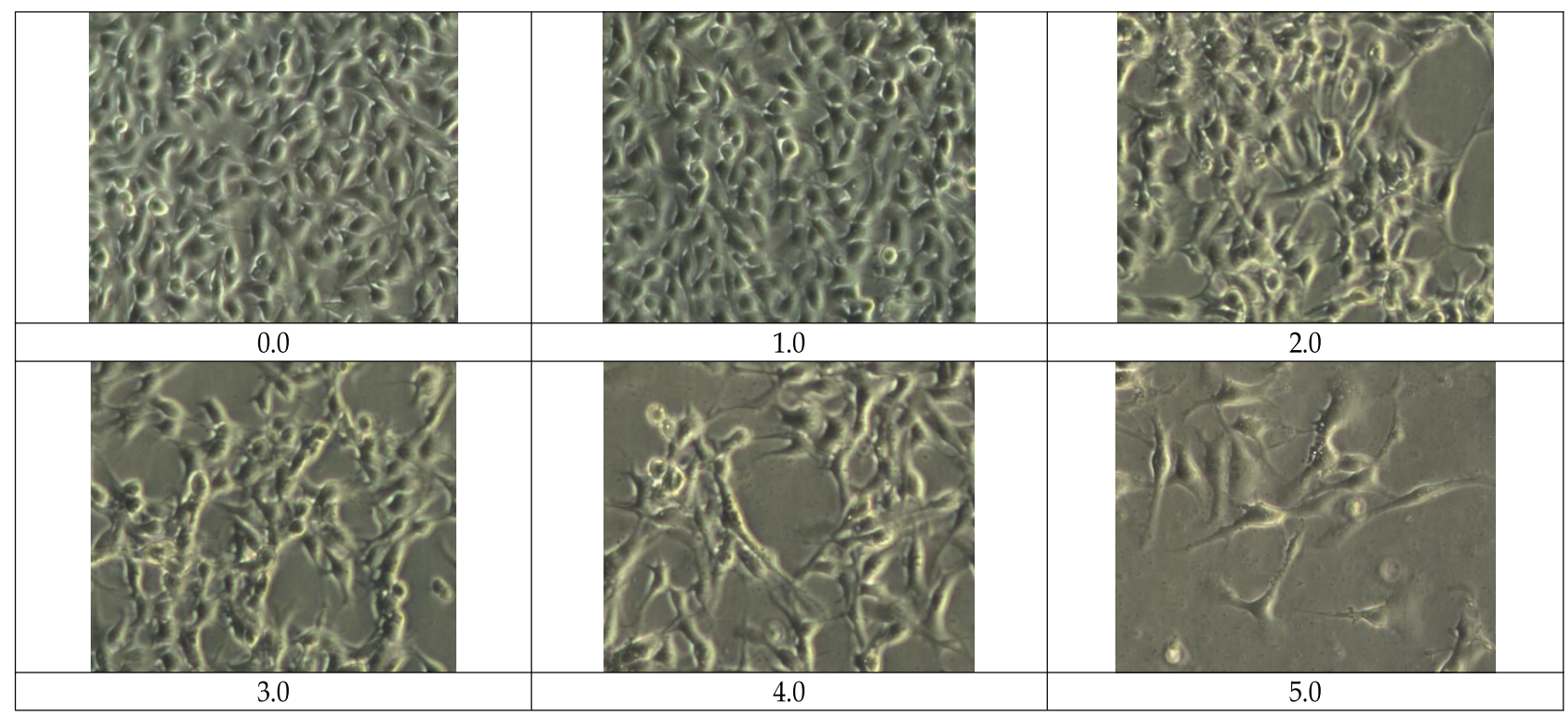

Fig. 3. Phase contrast images of primary human melanocytes (HEMa) in culture.

play important roles in controlling melanogenesis.

The decoction of inner film of bamboo is called as "Jukyeo" in Korea and is a traditionally recognized folk medicine used to vomiting blood (Haematemesis) in China and Korea. Similarly, the material of bamboo is currently available on the Chinese, Korea, and Japanese markets as an herbal tea for the purpose of blood-clearing. In the course of investigating the therapeutic effects of inner film on bamboo, we developed a renewed interest in the melanin synthesis-inhibitory ability of $\mathrm{HCl}$-ethanol extracts from the $P$.

\section{bambusoides.}

When tested in melanoma B16/F10 cells treated with the a-melanocyte stimulating hormone (a-MSH), the aqueous ethanol extract of Sasa quelpaertensis culm inhibited the cel-

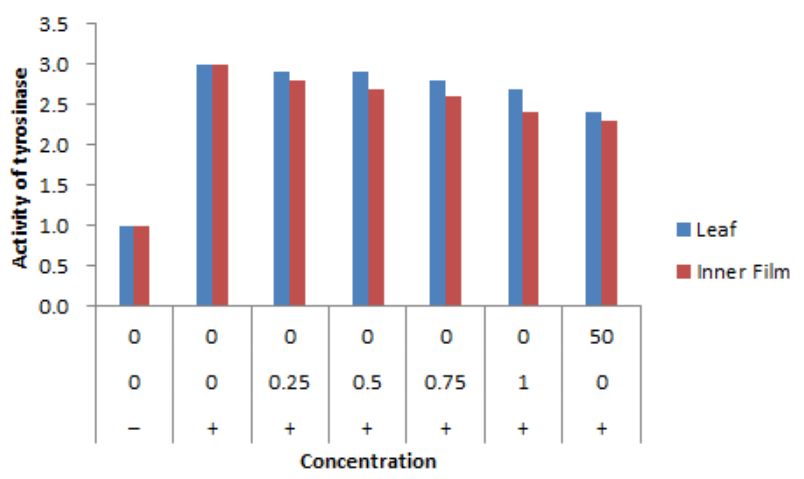

Fig. 4. Inhibitory effects of inner film compounds on intra cellular tyrosinase activity in melanin cells at $72 \mathrm{hr}$ after treatment. The values of concentrations were shown in Table 1. lular melanogenesis more effectively than its leaf extract [1]. These results of $S$. quelpaertensis were consistent withour results ( $P$. bambusoides). We concluded from that the bamboo compound including p-coumaric acid inhibited a-MSHstimulated cellular melanogenesis more effectively than arbutin or other structurally similar compounds including 3-(4-hydroxyphenyl) propionic acid, cinnamic acid and caffeic acid. It also attenuated a-MSH-dependent increase of tyrosinase protein.

Compared with unstimulated control, all extracts significantly reduced melanogenesis in human melanoma cells and normal adult epidermal melanocytes. These extracts also reduced melanin transfer and reduced filopodia expression on melanocytes, similar to hydroquinone and niacinamide, indicating their effectiveness as multimode pigmentation actives $[5,7,8]$.

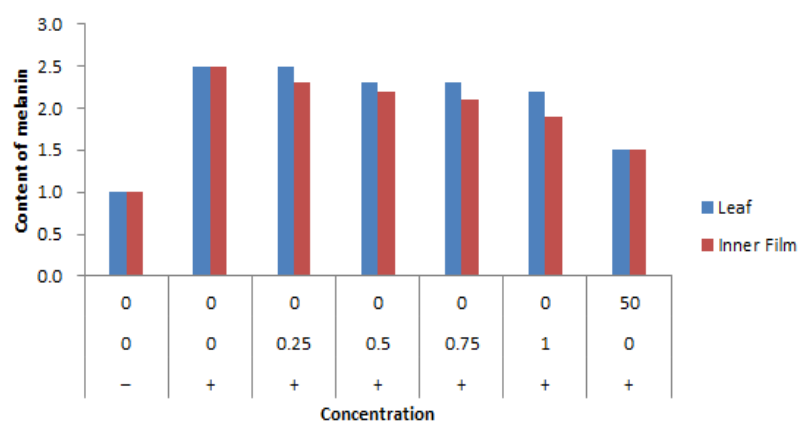

Fig. 5. Inhibitory effects of bamboo compounds on melanin content at $72 \mathrm{hr}$ after treatment. The values of concentrations were shown in Table 1. 
Plants extracts are good resources to find functional compounds for human health. For example, mulberry, kiwi, and Sophora angustifolia and some natural plant extracts were assessed against isobutylmethylxanthine, hydroquinone, vitamin C and niacinaoma [16]. These extracts significantly reduced also reduced melanogenesis in human melanoma cells and normal adult epidermal melanocytes. They also reduced melanin transfer in human skin cells [16]. In Korea, Kim et al. [8] reported that Inhibition of melanin synthesis of eight plant extracts, Acer psedo-siebolianum, Acer geiseum, Castanopsis cuspidata var. thunbergii, Acer ginnala, Cercidiphyllum japonica, Conus walteri, Distylum racemosum, Thuijopsis dolabrata cv. aurea showed the high at $1,000 \mathrm{mg}$ in tyrosinase inhibitory activity.

Recent elucidation of regulatory mechanisms of eu- and pheomelanogenesis has led us towards an exciting new era of melanogenesis control. Mishima et al. [12] reported that progress on inhibitory control of melanogenesis from the macromolecular level to human skin color and many new melanogenic inhibitors have been discovered which, in spite of their non-suppressive effect on isolated naked tyrosinase, suppress melanin formation in the living pigment cell in vitro as well as in the natural world.

\section{References}

1. An, S. M., Lee, S. I., Choi, S. W., Moon, S. W. and Boo, Y. C. 2008. p-Coumaric acid, a constituent of Sasa quelpaertensis Nakai, inhibits cellular melanogenesis stimulated by a melanocyte stimulating hormone. British J Dermatol 159, 292-299.

2. Chang, T. S. 2009. An updated review of tyrosinase inhibitors. Intl J Mol Sci 10, 2440-2475.

3. Hearing, V. J. and Tsukamoto, K. 1991. Enzymatic control of pigmentation in mammals. FASEB J 5, 2902-2909.

4. Hosei, J. E., Suda, T. and Kuroki, T. 1985. Regulation of melanin synthesis of B16 mouse melanoma cells by 1a,25-dehydroxyvitamin D3 and retinoic acid. Cancer Res 45, 1474-1478.

5. Hurley, M. E., Guevara, I. L., Gonzales, R. M. and Pandya,
A. G. 2002. Efficacy of glycolic acid peels in the treatment of melasma. Arch Dermatol 138, 1578-1582.

6. Jeon, S. H., Kim, K. H., Koh, J. U. and Kong, K. H. 2005. Inhibitory effects on L-dopa oxidation of tyrosinase by skin-whitening agents. Bull Korean Chem Soc 26, 1135-1137.

7. Jo, Y. O., Kong, Y. H., Lee, Y. C., Kim, S. S. and Choi, S. Y. 2008. Inhibitory effect of white Ginseng fraction on skin pigmentation. Korean J Med Crop Sci 16, 192-194.

8. Kim, J. Y., Lee, J. Y., Lee, W. Y., Yi, Y. and Lim, Y. 2010. Anti-oxidant property and inhibition of melanin synthesis of eight plant extracts. Korean J Microbiol Biotechnol 38, 414-419.

9. Kumar, C. M., Sathisha, U. V., Dharmesh, S., Rao, A. G. and Singh, S. A. 2011. Interaction of sesamol (3,4-methylenedioxyphenol) with tyrosinase and its effect on melanin synthesis. Biochimie 93, 562-569.

10. Lin, J. Y. and Fisher, D. E. 2007. Melanocyte biology and skin pigmentation. Nature 445, 843-850.

11. Maeda, K. and Fukuda, M. J. 1996. Arbutin: mechanism of its depigmenting action in human melanocyte culture. Pharmacol Exp Ther 276, 765-769.

12. Mishima, Y., Hatta, S., Ohyma, Y. and Inazu, M. 1988. Induction of melanogenesis suppression: cellular pharmacology and mode of differential action. Pigment Cell Res 1, 367-374.

13. Olivares, C. and Solano, F. 2009. New insights into the active site structure and catalytic mechanism of tyrosinase and its related proteins. Pigment Cell Melanoma Res 22, 750-760.

14. Park, J. H., Kim, Y. J., Mun, Y. J., Lee, Y. C. and Woo, W. H. 2005. Inhibitory effect of methanolic extract of Cnidiirhizoma on the Melanogenesis. Korean J Oriental Physiol Pathol 19, 938-944.

15. Seiji, M., Shimao, K., Birbeck, M. S. C. and Fitzpatrick, T. B. 1963. Subcellular location of melanin biosynthesis. Ann NY Acad Sci 100, 479-533.

16. Singh, S. K., Baker, R., Wibawa, J. I., Bell, M. and Tobin, D. J. 2013. The effects of Sophora angustifolia and other natural plant extracts on melanogenesis and melanin transfer in human skin cells. Exp Dermatol 22, 67-69.

17. Sugimoto, K., Nishimura, T., Nomura, K., Sugimoto, K. and Kuriki, T. 2004. Inhibitory effects of alpha-arbutin on melanin synthesis in cultured human melanoma cells and a three-dimensional human skin model. Biol Pharm Bull 27, 510-514. 


\section{초록 : 대잎 추출물의 멜라닌 합성과 타이로신 활성 저해 효과}

허만규 $^{*} \cdot$ 한민호 ${ }^{2,3} \cdot$ 박 철 $^{1} \cdot$ 최영현 $2^{2,3}$

(동의대학교 ${ }^{1}$ 자연과학대학 분자생물학과, ${ }^{2}$ 한의과대학 생화학교실, ${ }^{3}$ 항노화연구소 및 블루바이오소재개발 센터)

타이로신은 멜라닌 합성을 조절하는 효소이다. 본 연구에서는 현재까지 미백 효능에 대하여 연구가 진행되지 않은 대나무 중 왕대의 잎 및 대 속 내피 추출물이 유발하는 타이로시나제 활성 및 멜라닌 생성 억제 정도를 조사 하였다. 대 잎과 대 속 추출물을 $5 \mathrm{mg} / \mathrm{ml}$ 농도로 멜라닌 세포에 처리하면 세포의 생존율이 감소하는 것으로 나타 났다. 또한 세포독성이 없는 조건의 대 잎과 대 속 추출물을 처리하였을 경우 타이로시나제 활성이 억제되었으며, 멜라닌 생성도 억제되는 것으로 나타났다. 본 연구의 결과를 살펴볼 때 대나무 추출물이 타이로시나제 활성과 발현을 저해함으로써 멜라닌 생성을 억제할 수 있는 후보군으로 가능성이 있는 것으로 생각된다. 